\title{
ASAS KEBEBASAN BERKONTRAK DALAM PERJANJIAN KERJA ANTARA TANAMAS INDUSTRY COMMUNITY DENGAN KARYAWAN DI KOTA CIREBON
}

\author{
Solikhah, Busro Achmad \\ Magister Kenotariatan, Fakultas Hukum, Universitas Diponogoro \\ Jl. Imam Barjo Pleburan, Semarang, 50241 \\ solikhah.kusuma2016@gmail.com
}

\begin{abstract}
This research want to know how the implementation of the principle freedom of contract in employment agreement between employees and Tanamas Industry Community. The method used in this study is empirical juridical. If viewed from the contents of the agreement for a certain time does not meet the principle of proportionality and may harm the employees because some of the contents of it, requires employees to obey the rules which is set by company.
\end{abstract}

Keywords: Principle of Freedom of Contract, Employment Agreement

\begin{abstract}
Abstrak
Penelitian ini bertujuan mengetahui implementasi asas kebebasan berkontrak dalam perjanjian kerja antara karyawan dan Tanamas Industry Community di Kota Cirebon. Metode yang digunakan adalah menggunakan penelitian hukum Yuridis Empiris. Implementasi asas kebebasan berkontrak dalam pelaksanaan perjanjian kerja tersebut, jika ditinjau dari isi perjanjian untuk waktu tertentu tersebut tidak memenuhi asas proporsionalitas serta dapat merugikan karyawan karena sebagian dari isi perjanjian kerja tersebut mewajibkan karyawan mentaati peraturan yang telah ditetapkan oleh perusahaan.
\end{abstract}

Kata Kunci: Asas Kebebasan Berkontrak, Perjanjian Kerja.

\section{A. Pendahuluan}

Perkembangan kebebasan berkontrak dapat mendatangkan ketidakadilan karena prinsip ini hanya dapat mencapai tujuannya, yaitu mendatangkan kesejahteraan seoptimal mungkin, bila para pihak memiliki bargaining power yang seimbang. Dalam kenyataan hal tersebut sering tidak terjadi demikian sehingga negara menganggap perlu campur tangan untuk melindungi pihak yang lemah. Dalam perkembangannya, kebebasan berkontrak hanya bisa mencapai tujuan bila para pihak mempunyai bargaining position yang seimbang. Jika salah satu pihak lemah maka pihak yang memiliki bargaining position lebih kuat dapat memaksakan kehendaknya untuk menekan pihak lain demi keuntungan dirinya sendiri. Syarat-syarat atau ketentuan dalam kontrak/perjanjian untuk waktu tertentu yang semacam itu akhirnya akan melanggar aturanaturan yang adil dan layak. 
Keadaan tersebut di atas bisa berlaku dalam hubungan perjanjian antara pemberi kerja dengan buruh yang kemudian menimbulkan hal-hal yang negatif dalam arti pihak yang mempunyai bargaining position yang kuat dapat memaksakan kehendaknya kepada pihak yang lemah, dan pihak yang kuat mendapat keuntungan dari tindakannya tersebut. Asas kebebasan berkontrak ini terkandung dalam Pasal 1338 ayat 1 KUH Perdata yang berbunyi: "Semua perjanjian yang dibuat secara sah berlaku sebagai undang-undang bagi mereka yang membuatnya". Dengan menekankan pada perkataan semua, maka Pasal tersebut seolah-olah berisikan suatu pernyataan kepada masyarakat diperbolehkan membuat perjanjian yang berupa dan berisi tentang apa saja dan diperolehkan pula membuat undang-undang sendiri, asalkan tidak bertentangan dengan undang-undang, ketertiban umum, dan kesusilaan. Lebih tegasnya para pihak yang membuat perjanjian dapat menciptakan suatu ketentuan sendiri untuk kepentingan mereka sesuai dengan apa yang dikehendaki.

Sementara itu dalam Undang-undang Nomor 13 Tahun 2003 tentang Ketenagakerjaan merupakan salah satu solusi dalam perlindungan buruh maupun pemberi kerja tentang hak dan kewajiban masing-masing pihak. Undang-Undang Nomor 13 Tahun 2003 sangat berarti dalam mengatur hak dan kewajiban baik para tenaga kerja maupun para pengusaha di dalam melaksanakan suatu mekanisme proses produksi. Tidak kalah pentingnya adalah perlindungan tenaga kerja yang bertujuan agar bisa menjamin hak-hak dasar pekerja/buruh dan menjamin kesempatan serta perlakuan tanpa diskriminasi. Hal ini merupakan esensi dari disusunya undangundang ketenagakerjaan yaitu mewujudkan kesejahteraan para pekerja/buruh yang akan berimbas terhadap kemajuan dunia usaha di Indonesia.

Dalam perkembangannya, kebebasan berkontrak hanya bisa mencapai tujuan bila para pihak mempunyai bargaining position yang seimbang. Jika salah satu pihak lemah maka pihak yang memiliki bargaining position lebih kuat dapat memaksakan kehendaknya untuk menekan pihak lain demi keuntungan dirinya sendiri. Syarat-syarat atau ketentuan dalam kontrak/ perjanjian untuk waktu tertentu yang semacam itu akhirnya akan melanggar aturan-aturan yang adil dan layak.

Perusahaan Tanamas Industry Community di Cirebon adalah perusahaan yang bergerak di bidang perkebunan, perindustrian, perdagangan dan konsultasi. Dalam usahanya tidak terlepas dari kerjasama dengan perusahaan lain atau pihak lain yang mendukung kelancaran dan kemajuan usahanya. Di samping itu perusahaan juga memperkerjakan karyawan-karyawan yang jumlah cukup banyak. Dengan demikian dalam usaha tersebut timbul suatu perjanjian-perjanjian 
demi kemajuan dan perkembangan perusahaan sehingga mengikatkan diri sesuai dengan isi perjanjian kerja tersebut.

Masing-masing pihak yaitu perusahaan dan para karyawan mempunyai hak dan kewajiban tertentu yang telah ditetapkan dalam perjanjian. Salah satu bentuk perjanjiannya adalah perjanjian kerja untuk waktu tertentu, maksudnya adalah jangka waktu yang telah ditentukan lebih dahulu, yang digantungkan pada jangka waktu sampai pekerjaan selesai. Jadi pada kerja yang tidak ditentukan waktunya dikaitkan dengan lamanya pekerjaan selesai. Apabila pekerjaan selesai, jangka waktu kerja sama dengan jumlah waktu menyiapkan kerja. Makna jangka waktu bisa dihubungkan tujuan penyelesaian pekerjaan.

\section{B. Metode Penelitian}

Penelitian ini merupakan pendekatan yuridis-empiris. Pendekatan yuridis digunakan untuk menganalisis berbagai peraturan perundang-undangan dan hukum perjanjian serta penerapan analisisi kebebasan berkontrak pada perjanjian kerja pada Tanamas Industry Community di Cirebon dengan calon pekerja. Sementara itu pendekatan penelitian hukum empiris adalah penelitian yang mengacu kepada norma-norma dan asas-asas hukum yang terdapat dalam peraturan perundang-undangan dan putusan pengadilan.

Tiga alasan penggunaan penelitian hukum empiris yang bersifat kualitatif.Pertama, analisis kualitatif didasarkan pada paradigma hubungan dinamis antara teori, konsep-konsep dan data yang merupakan umpan balik atau modifikasi yang tetap dari teori dan konsep yang di dasarkan pada yang dikumpulkan. Kedua, data yang akan dianalisis beraneka ragam, memiliki sifat dasar yang berbeda antara yang satu dengan lainnya, serta tidak mudah untuk dikuantifsir. Ketiga, sifat dasar data yang akan dianalisis dalam penelitian adalah bersifat menyeluruh dan merupakan suatu kesatuan yang integral, dimana hal itu menunjukkan adanya keanekaragaman data serta memerlukan informasi yang mendalam (indepth information).

Ketiga kriteria penelitian kualitatif tersebut terdapat dalam penelitian tesis ini, sehingga sangat beralasan menggunakan metode kualitatif dalam analisis data. Penelitian ini bersifat menyeluruh karena berupaya mendalami keseluruhannya. Penelitian ini juga berupaya mencari hubungan yang harmonis dari konsep-konsep yang ditemukan dalam bahan-bahan hukum primer dan skunder dengan menggunakan teori atau doktrin-doktrin hukum.

\section{Hasil dan Pembahasan}

1. Alasan Tanamas Industry Community di Kota Cirebon Mengikat Buruh Dengan Perjanjian kerja 
Pada umumnya perjanjian kerja dibuat secara lisan maka pengusaha wajib membuat surat pengangkatan bagi pekerja/buruh yang bersangkutan. Surat pengangkatan sebagaimana dimaksud sekurang- kurangnya memuat keterangan:

1) Nama dan alamat pekerja/buruh.

2) Tanggal mulai bekerja.

3) Jenis pekerjaan dan

4) Besarnya upah.

Alasan manajemen Tanamas Industry Community Kota Cirebon mengikat tenaga kerja dalam perjanjian kerja untuk waktu karena pekerjaan yang berlangsung di Tanamas Industry Community Kota Cirebon menurut sifat, jenis atau kegiatannya akan selesai dalam waktu tertentu, pekerjaan tersebut adalah, Sebagaimana yang diatur dalam Undang-Undang No. 13 tahun 2003 tentang Ketenagakerjaan pasal 63 ayat (1) dan (2) :

(1) Yang sekali selesai atau sementara sifatnya.

(2) Yang diperkirakan penyelesaian dalam waktu tidak terlalu lama dan paling lama tiga tahun.

(3) Yang bersifat musiman atau berulang kali.

(4) Yang bukan merupakan kegiatan yang bersifat tetap dan tidak terputus- putus.

(5) Yang berhubungan dengan produk atau kegiatan baru atau tambahan yang masih dalam percobaan atau penjajagan.

Sejalan dengan penjelasan diatas Wawan setiawan menerangkan bahwa Tanamas Industry Community dalam memberikan kontrak jangak pendek atau disebut dengan perjanjian kerja kepada masyarkat di Kota Cirebon adalah dengan alasan kegiatan dan tujuan usaha dari Tanamas Industry Community yang notabennya adalah bergerak di bidang perkebunan, jika dilihat dari struktur organisasi Tanamas Industry Community telah memilik komponenkomponen pekerja yang solid di bidang masing-masing dengan sustim recruitment yang ketat dan tertib, sehingga untuk masyarakat Kota Cirebon yang sangat membutuhkan pekerjaan, Tanaman Coummunity Industry hanya memberikan jenis pekerjaan yang bersifat musiman atau tidak tetap, jika dilihat dari spesifikasi pekeerjaannya, dapat dilihat pada musim kebun panen yang karena hal tersebut Tanaman Coummunity Industry memang sangat membutuhkan tenaga kerja tersebut dengan harapan dapat memaksimalkan hasil panen yang ada dan mengembangkan perekonomian masyarakat Kota Cirebon.

Selain dari penjelasan yang telah dikemukakan diatas Tanamas Industry Community juga mewajibkan setiap karyawan untuk menandatangani dan menerima General Staff 
Handbook yang telah ditetapkan oleh Tanamas Industry Community. General Staff Handbook berisikan aturan-aturan yang mengikat antara kedua belah pihak. Isi dari General Staff Handbook ini ditentukan oleh perusahaan, dengan arti bahwa pekerja yang telah menandatanginya wajib mengikuti segala aturan-aturan yang ada di dalamnya. Sebenarnya isi dari General Staff Handbook ini tidak jauh berbeda dengan perjanjian kerja, hanya saja sifatnya bersifat umum yang dalam artian aturan-aturan yang tertulis di dalamnya tidak hanya diwajibkan kepada satu atau dua pekerja saja dan tidak juga diwajibkan kepada pekerja berdasarkan jabatan tertentu namun ketentuan-ketentuan tersebut diwajibkan kepada seluruh pekerja. Adapun isi dari General Staff Handbook secara garis besar yang telah dijelaskan oleh Wawan setiawan berisikan mengenai hal-hal sebagai berikut:

a. Kebijakan perusahaan atas kesempatan kerja yang sama bagi seluruh pekerja dan calon pekerja.

Perusahaan menyadari bahwa kesempatan kerja merupakan hak setiap individu dan tidak dapat dihalang- halangi hanya karena perbedaan jenis kelamin, status pernikahan, ada atau tidak adanya tanggungan, agama atau kepercayaan atau pandangan politik, ras (warna kulit, kewarganegaraan, etnik dan daerah asal), ketidakmampuan fisik, dan umur. Kebijakan ini menyatakan bahwa perusahaan akan memperlakukan setiap individu sama dalam hal hak untuk memperoleh pekerjaan. Dengan kata lain kesempatan pekerjaan yang diberikan secara bebas kepada setiap orang akan dinilai secara obyektif berdasarkan keahliannya, kesanggupannya dalam bekerja dan bukan secara subyektif dari pihak-pihak yang melaksanakan proses rekruitmen.

b. Ketentuan-ketentuan umum hubungan kerja, dokumentasi kepersonaliaan, kesempatan promosi kerja dan pelatihan kerja.

Di dalam ketentuan-ketentuan ini mengatur tentang masa percobaan selama tiga bulan. Namun tidak disebutkan jenis perjanjian kerja yang bagaimana dapat mewajibkan syarat ini. Selain itu, diatur juga mengenai dokumentasi kepersonaliaan dalam hal penggunaan dokumen-dokumen, tata cara untuk mengirimkan dokumen kerja kepada rekan kerja, dan pelatihan kerja yang disediakan oleh perusahaan sebagai bentuk upaya dalam pengembangan keahlian pekerja.

c. Ketentuan mengenai jam kerja dan cuti tahunan.

Jam kerja ditetapkan sebanyak 40 jam per minggu dari jam Sembilan pagi sampai jam lima sore, mulai hari Senin hingga Jumat. Cuti tahunan ditetapkan sebanyak lima minggu dalam setahun atau setara dengan 25 hari kerja. 
d. Kebijakan keselamatan dan kesehatan kerja.

Kebijakan ini menyebutkan bahwa perusahan dan pekerja masing-masing diwajibkan untuk saling menjaga keselamatan dan kesehatan di lingkungan kerja dan perusahaan akan merujuk pada ketentuan mengenai keselamatan dan kesehatan kerja yang diatur oleh pemerintah setempat. Di dalam kebijakan ini tidak disebutkan mengenai jumlah tunjangan (apakah bersifat tunjangan tetap atau tidak tetap) keselamatan dan kesehatan kerja yang disediakan sendiri oleh perusahaan.

e. Prosedur mengenai pengeluaran.

Pengeluaran yang dimaksud adalah pengeluaran- pengeluaran yang dibutuhkan oleh setiap pekerja yang digunakan dalam rangka melaksanakan tugasnya. Tidak disebutkan pembatasan akan besaran pengeluaran yang diperbolehkan hanya saja disebutkan bahwa dikarenakan perusahaan merupakan organisasi non profit maka segala sesuatu mengenai pengeluaran bisnis hendaknya dilakukan sewajarnya. Setiap pekerja diwajibkan untuk mengikuti panduan permintaan dana yang diperlukan sesuai dengan yang telah ditentukan oleh perusahaan dan membuat laporan atas pengeluaran yang ada.

f. Ketentuan mengenai standar komunikasi dan penggunaan teknologi informasi.

Ketentuan ini mengatur tentang tata cara penggunaan alat komunikasi yang dipakai untuk bekerja seperti computer dan email untuk dapat digunakan sebagai sarana komunikasi yang baik antar sesame pekerja.

g. Prosedur tindakan disiplin.

Ketentuan ini mengatur tentang prosedur tindakan disiplin yang diberikan perusahaan kepada pekerja yang melakukan pelanggaran kerja. Secara prinsip perusahaan akan memperlakuan sama dan dengan serius setiap pekerja yang melakukan pelanggaran terlepas dari penilaian-penilaian subyektif yang diberikan kepadanya. Disebutkan bahwa otoritas dalam memberikan keputusan berada di tangan Direktur, namun atasan langsung pekerja diberi hak untuk memberikan peringatan lisan atau tertulis kepada bawahannya

Perjanjian kerja Tanamas Industry Community telah dibuat terlebih dahulu oleh pengusaha dan karyawan hanya tinggal menandatangani saja. Segala ketentuan dan syarat yang ada di dalam perjanjian tersebut yang mengatur mengenai lamanya perjanjian, besaran upah, waktu kerja, cuti, dan lain sebagainya telah diatur dan ditetapkan secara sepihak oleh Tanamas Industry Community.

Bilamana masa waktu perjanjian kerja ini habis, tidak menutup kemungkinan akan diperpanjang untuk kurun waktu tertentu pula. Perpanjangan ini harus mendapat persetujuan 
kedua belah pihak yakni oleh Tanamas Industry Community dan karyawan yang bersangkutan. Hal-hal yang diatur dalam perjanjian kerja Tanamas Industry Community adalah mengenai hak dan kewajiban para pihak. Adapun para pihak yang tercantum dalam perjanjian kerja Tanamas Industry Community adalah Tanamas Industry Community sebagai Pihak Pertama (sebagai pengusaha/pemberi kerja) dan M. Harsoyo sebagai Pihak Kedua (sebagai karyawan). Masingmasing pihak memiliki hak dan kewajiban tersendiri yang mana diharapkan untuk dapat dilaksanakan sesuai dengan isi perjanjian kerja demi mencapai hubungan kerja yang diharapkan. Hak dan kewajiban masing-masing pihak yang selanjutnya akan disebutkan di bawah ini juga merujuk pada General Staff Handbook.

Adapun hak dan kewajiban dari masing-masing pihak akan diuraikan sebagaimana dalam tabel-tabel berikut ini:

\section{Hak-Hak Para Pihak}

\begin{tabular}{|c|c|c|}
\hline No & Hak Pihak Pertama & Hak Pihak Kedua \\
\hline 1 & $\begin{array}{l}\text { Berhak atas keahlian dan kemampuan } \\
\text { Pihak Pertama sesuai dengan jabatan } \\
\text { yang diberikan. }\end{array}$ & $\begin{array}{l}\text { Kompensasi berupa gaji kotor sejumlah Rp. } 450.000 . \\
\text { Tanggapan: Jumlah gaji kotor ditentukan sepihak oleh Pihak } \\
\text { Pertama, sedangkan Pihak Kedua tidak memiliki kesempatan } \\
\text { sama sekali untuk melakukanpenawaran atas gaji yang } \\
\text { diharapkannya. Lebih lanjut, pekerja berhak atas upah } \\
\text { lembur atas jam-jam kerja lembur yang dilakukan oleh } \\
\text { pekerja. }\end{array}$ \\
\hline 2 & $\begin{array}{l}\text { Waktu kerja selama delapan jam } \\
\text { sehari atau } 40 \text { jam seminggu. }\end{array}$ & $\begin{array}{l}\text { Pembayaran kembali untuk tujuan rekruitmen berupa: } \\
\text { 1) Biaya perjalanan dari rumah ke lokasi kerja baru. } \\
\text { 2) Biaya penginapan lima malam. }\end{array}$ \\
\hline 3 & $\begin{array}{l}\text { Dapat menghendaki Pihak Kedua } \\
\text { untuk bekerja di hari libur. }\end{array}$ & $\begin{array}{l}\text { Cuti tahunan sebanyak } 25 \text { hari kerja dan tambahan untuk } \\
\text { libur setiap hari libur nasional. }\end{array}$ \\
\hline 4 & $\begin{array}{l}\text { Mengikutsertakan Pihak Kedua dalam } \\
\text { program asuransi pemeliharaan } \\
\text { kesehatan yang diselenggarakan Pihak } \\
\text { Pertama. }\end{array}$ & $\begin{array}{l}\text { THR sejumlah satu bulan gaji } \\
\text { kotor atau prorata bila masa kerja } \\
\text { belum mencapai } 12 \text { bulan. }\end{array}$ \\
\hline 5 & $\begin{array}{l}\text { Melakukan tindakan yang sesuai dengan } \\
\text { peraturan yang berlaku jika Pihak Kedua } \\
\text { melakukan pelanggaran. } \\
\text { Tanggapan: Mengenai tindakan yang } \\
\text { dimaksud di dalam pasal ini tidak } \\
\text { disebutkan jenis-jenis tindakan apa saja } \\
\text { yang termasuk dalam pelanggaran aturan } \\
\text { perusahaan. }\end{array}$ & $\begin{array}{l}\text { Menerima penggantian biaya- biaya pengobatan maksimum } \\
\text { sebesar plafon yang diberikan selama setahun. } \\
\text { Tanggapan: Besaran plafon kesehatan tidak ada disebutkan di } \\
\text { dalam perjanjian dan tata cara atau prosedur penggantian } \\
\text { juga tidak disebutkan dalam pasal ini. }\end{array}$ \\
\hline 6 & $\begin{array}{l}\text { Laporan keuangan atas semua barang } \\
\text { yang dibeli dan dijual, uang yang } \\
\text { diterima dan dibayar dan semua hal } \\
\text { apapun yang berhubungan dengan usaha } \\
\text { Perusahaan. }\end{array}$ & \\
\hline
\end{tabular}




\begin{tabular}{|l|l|l|}
\hline & & \\
\hline 7 & & Diperlakukan sama dalam hal kesempatan kerja \\
\hline
\end{tabular}

\section{Kewajiban Para Pihak}

\begin{tabular}{|c|c|c|}
\hline No & Kewajiban Pihak Pertama & Kewajiban Pihak Kedua \\
\hline 1 & $\begin{array}{l}\text { Memberikan kompensasi berupa gaji } \\
\text { kotor kepada Pihak Kedua sejumlah Rp. } \\
\text { 450.000,- }\end{array}$ & $\begin{array}{l}\text { Bekerja selama delapan jam sehari atau } 40 \text { jam seminggu } \\
\text { dari Senin s/d Jumat dalam menjalankan tugasnya sesuai } \\
\text { dengan keahlian yang dimiliki dalam menjabat tugas } \\
\text { sebagaimana yang diemban }\end{array}$ \\
\hline 2 & $\begin{array}{l}\text { Membayar kembali jumlah yang } \\
\text { dibayarkan karyawan untuk tujuan } \\
\text { perekruitan karyawan ke lokasi kerja. }\end{array}$ & $\begin{array}{l}\text { Mengikuti program asuransi pemeliharaan kesehatan yang } \\
\text { diselenggarakan Pihak Pertama }\end{array}$ \\
\hline 3 & $\begin{array}{l}\text { Memberikan cuti tahunan sebanyak } 25 \\
\text { hari kerja dalam satu tahun kalender. }\end{array}$ & $\begin{array}{l}\text { Mengikuti program JHT dengan } \\
\text { menanggung tanggungan sebesar } \\
0.7 \% \text {. }\end{array}$ \\
\hline 4 & $\begin{array}{l}\text { Memberikan THR sejumlah satu bulan } \\
\text { gaji kotor atau prorata bila masa kerja } \\
\text { bulan belum mencapai } 12 \text {. }\end{array}$ & Menjaga kerahasiaan perusahaan kepada pihak lain. \\
\hline 5 & $\begin{array}{l}\text { Memberikan penggantian atas biaya- } \\
\text { biaya pengobatan maksimum sebesar } \\
\text { plafon yang diberikan selama setahun. }\end{array}$ & Menjaga keamanan perusahaan \\
\hline 6 & & $\begin{array}{l}\text { Memberi tenggang waktu selama satu bulan dimuka sebelum } \\
\text { tanggal pengunduran diri yang ditujukan kepada Pihak } \\
\text { Pertama. }\end{array}$ \\
\hline 7 & & $\begin{array}{l}\text { Memberikan laporan keuangan dengan lengkap atas semua } \\
\text { barang yang dibeli dan dijual, uang yang diterima dan } \\
\text { dibayar dan semua hal apapun yang berhubungan dengan } \\
\text { usaha Perusahaan dan berkomitment untuk menjaganya } \\
\text { dengan baik }\end{array}$ \\
\hline
\end{tabular}

Berdasarkan keterangan tabel diatas, pada hekekatnya segala hak dan kewajiban dari pengusaha dan karyawan merupakan peranan-peranan yang letaknya saling berhadapan dan sifatnya timbal balik antara satu dengan lainnya yang berasaskan keadilan.

Hal ini sejalan dengan apa yang dikemukakan oleh Aris Toteles bahwa keadilan merupakan suatu bentuk kondisi kebenaran ideal secara moral akan sesuatu hal, baik itu menyangkut benda ataupun orang. Menurut dari sebagian besar teori, keadilan memiliki tingkat kepentingan yang besar. Kebanyakan orang percaya jika ketidakadilan harus segera dilawan dan dihukum, serta banyak gerakan sosial dan politis yang ada di seluruh dunia memperjuangkan menegakkan keadilan. Dalam bahasa inggris, keadilan adalah justice. Justice itu sendiri terdiri atas dua makna, yaitu makna justice secara atribut dan makna justice secara tindakan. Makna justice secara atribut merupakan suatu kausalitas yang adil. Sementara itu makna justice secara tindakan merupakan tindakan menjalankan dan menentukan hak atau hukuman. Keadilan ini 
memiliki arti tidak berat sebelah, tidak memihak, berpihak kepada yang benar dan tidak sewenang-wenang.

\section{Implementasi Asas Kebebasan Berkontrak Dalam Pelaksanaan Perjanjian Kerja Antara Buruh Dan Tanamas Industry Community Di Kota Cirebon}

Tanamas Industry Community Kota Cirebon dalam usahanya tidak terlepas dari kerjasama dengan perusahaan lain atau pihak lain yang mendukung kelancaran dan kemajuan usahanya. Di samping itu perusahaan juga memperkerjakan karyawan-karyawan yang jumlah cukup banyak. Dengan demikian dalam usaha tersebut timbul suatu perjanjian-perjanjian demi kemajuan dan perkembangan perusahaan sehingga mengikatkan diri sesuai dengan isi perjanjian kerja tersebut. Masing-masing pihak yaitu perusahaan dan para karyawan mempunyai hak dan kewajiban tertentu yang telah ditetapkan dalam perjanjian. Salah satu bentuk perjanjiannya adalah perjanjian kerja untuk waktu tertentu, maksudnya adalah jangka waktu yang telah ditentukan lebih dahulu, yang digantungkan pada jangka waktu sampai pekerjaan selesai. Jadi pada kerja yang tidak ditentukan waktunya dikaitkan dengan lamanya pekerjaan selesai. Apabila pekerjaan selesai, jangka waktu kerja sama dengan jumlah waktu menyiapkan kerja. Makna jangka waktu bisa dihubungkan tujuan penyelesaian pekerjaan.

Kesepakatan kedua belah pihak dalam perjanjian kerja yang lazim disebut kesepakatan, bagi yang mengikatkan dirinya maksudnya bahwa pihak-pihak yang mengadakan perjanjian kerja harus setuju/sepakat. Mengenai hal-hal yang diperjanjikan. Apa yang dikehendaki pihak yang satu dikehendaki pihak yang lain. Pihak pekerja menerima pekerjaan yang ditawarkan, dan pihak pengusaha menerima pekerja tersebut untuk dipekerjakan.

Bertolak belakang dari penjelasan diatas, asas kebebasan berkontrak mengandung arti bahwa seseorang bebas membuat atau tidak membuat perjanjian, bebas menentukan isi berlakunya dan syarat-syarat perjanjian dengan bentuk tertentu atau tidak dan bebas memilih undang-undang mana yang akan dipakainya untuk perjanjian itu. Asas kebebasan berkontrak (freedom of contract) dapat di simpulkan dari ketentuan Pasal 1338 ayat (1) KUH Perdata, yang menyatakan bahwa semua perjanjian yang dibuat secara sah akan mengikat sebagai undangundang bagi para pembuatnya dan bila dihubungkan dengan tujuan hukum oleh Gustav Radbruch yaitu keadilan, kepastian dan kemanfaatan. Untuk keadilan, hak dan kewajiban pihak yang satu tidak boleh merugikan hak dan kewajiban pihak yang lain. Untuk kepastian, seluruh pihak harus dengan sungguh-sungguh memperhatikan dan melaksanakan hak dan kewajibannya masing-masing, dan sedangkan untuk kemanfaatan, perjanjian yang dibuat harus memberi manfaat kepada seluruh pihak. 
Makna asas kebebasan berkontrak adalah bahwa setiap orang pada dasarnya boleh membuat perjanjian yang berisi dan macam apa pun, asal tidak bertentangan dengan undangundang, kesusilaan dan ketertiban umum. Atau dengan pengertian lain asas kebebasan berkontrak memberikan kebebasan yang seluas-luasnya kepada masyarakat, untuk mengadakan perjanjian yang berisi apa saja dan dalam bentuk apa saja, sepanjang tidak melanggar undangundang, ketertiban umum dan kesusilaan.

Menurut Abdul Kadir dalam Djumadi menyebutkan bahwa di dalam suatu perjanjian termuat beberapa unsur, yaitu (Djumadi, 1995):

(a) Ada pihak-pihak

Pihak-pihak yang ada disini paling sedikit harus ada dua orang. Para pihak bertindak sebagai subyek perjanjian tersebut, Subyek mana bisa terdiri dari manusia atau badan hukum. Dalam hal para pihak terdiri dari manusia, maka orang tersebut harus telah dewasa dan cakap untuk melakukan hubungan hukum.

(b) Ada persetujuan antara para pihak

Para pihak sebelum membuat suatu perjanjian atau dalam membuat suatu perjanjian haruslah diberikan kebebasan untuk mengadakan bargaining atau tawar-menawar di antara keduanya, hal ini biasa disebut dengan asas konsensualitas dalam suatu perjanjian. Konsensus mana harus tanpa disertai dengan paksaan, tipuan dan kehakiman.

(c) Ada tujuan yang akan dicapai

Suatu perjanjian haruslah mempunyai satu atau beberapa tujuan tertentu yang ingin dicapai, dan dengan perjanjian itulah tujuan tersebut ingin dicapai atau dengan sarana perjanjian tersebut suatu tujuan ingin mereke capai, baik yang dilakukan sendiri maupun oleh pihak lain, yang dalam hal ini mereka selaku subyek dalam perjanjian tersebut. Dalam mencapai satu atau beberapa tujuan tertentu, para pihak terkait dengan adanya ketentuan bahwa tujuan tersebut tidak boleh bertentangan dengan undang-undang, kesusilaan dan ketertiban umum.

(d) Ada prestasi yang harus dilaksanakan

Para pihak dalam suatu perjanjian mempunyai hak dan kewajiban tertentu, yang satu dengan yang lainnya saling berlawanan. Apabila pihak yang satu berkewajiban untuk memenuhi suatu prestasi, maka bagi pihak lain hal tersebut adalah merupakan hak dan begitu pun sebaliknya.

(e) Ada bentuk tertentu

Suatu perjanjian dapat dibuat secara lisan maupun tertulis, dalam hal suatu perjanjian 
yang dibuat secara tertulis dan dibuat dalam suatu akta maka akta tersebut bisa dibuat secara autentik maupun dibawah tangan. Akta yang dibuat secara autentik adalah akta perjanjian yang dibuat oleh para pihak di hadapan seorang pejabat uum yang diberi wewenang untuk itu.

(f) Ada syarat-syarat tertentu

Dalam suatu perjanjian tentang isinya, harus ada syarat- syarat tertentu, karena dalam suatu perjanjian menurut ketentuan Pasal 1338 KUH Perdata ayat (1) menentukan bahwa suatu perjanjian atau peretujuan adalah mengikat sebagai undang- undang bagi mereka yang membuatnya. Dan agar suatu perjanjian bisa dikatakan sebagai suatu perjanjian yang sah adalah bilamana perjanjian tersebur telah memnuhi syarat-syarat tertentu.

Bila melihat dari unsur-unsur perjanjian yang telah dikemukakan diatas maka dapatlah diketahui unsur-unsur yang terkandung dalam perjanjian kerja Tanamas Industry Community, yakni:

(a) Adanya pihak-pihak

Keterangan mengenai para pihak yang mengadakan perjanjian di dalam perjanjian kerja di Tanamas Industry Community dapat dilihat pada bagian pendahuluan. Dalam perjanjian kerja yang dibuat oleh Tanamas Industry Community terdapat dua pihak yang mengikatkan diri dalam perjanjian kerja tersebut yaitu Tanamas Industry Community sebagai Pihak Pertama ataupun sebagai pengusaha dan Karyawan sebagai Pihak Kedua ataupun sebagai penerima kerja. Kemudian untuk ukuran kecakapan dan kedewasaan para pihak dalam membuat suatu perjanjian kerja adalah bila telah berusia 21 tahun atau telah menikah sehingga dapat dikatakan bahwa kedua belah pihak dalam perjanjian kerja tersebut adalah orang-orang yang telah dewasa dan cakap dalam bertindak.

(b) Ada persetujuan antara para pihak

Persetujuan kedua belah pihak atas perjanjian kerja di Tanamas Industry Community disebutkan pada bagian resital yang berbunyi sebagai berikut:

Pada bagian resital: "Kedua belah pihak secara bersama-sama sepakat untuk membuat Kesepakatan Kerja Waktu Tertentu (KKWT) sesuai dengan syarat dan ketentuan sebagai berikut:"

Dalam perjanjian kerja yang dibuat oleh Tanamas Industry Community tersebut sebenarnya tidak terkandung unsur kebebasan untuk mengadakan tawar-menawar atas isi perjanjian, hal ini dikarenakan bahwa perjanjian kerja tersebut dibuat secara baku. Artinya bahwa perjanjian kerja tersebut hanya dibuat oleh Pihak Pertama saja, namun dengan adanya kata-kata: 
"Kedua belah pihak secara bersama-sama sepakat untuk membuat Kesepakatan Perjanjian kerja (PKWT)" maka seolah-olah perjanjian kerja tersebut dibuat secara bersama-sama dimana Pihak Kedua juga ikut andil dalam pembuatan isi perjanjian dan bukan hanya Pihak Pertama saja.

Namun persetujuan dalam perjanjian kerja tersebut dinyatakan sah karena masing-masing pihak menandatangani perjanjian tersebut yang diartikan sebagai bentuk persetujuan para pihak atas isi perjanjian kerja tersebut.

(c) Ada tujuan yang akan dicapai

Tujuan utama yang hendak dicapai dengan mengadakan perjanjian kerja adalah untuk terciptanya hubungan kerja antara kedua belah pihak. Hal ini disebutkan didalam Pasal 1 tentang Luasnya Kesepakatan yang berbunyi demikian: Pasal 1 tentang Luasnya Kesepakatan: "Pihak Pertama akan memperkerjakan pihak Kedua pada perusahaan Pihak Pertama sesuai dengan keahlian dan kemampuan kerja Pihak Kedua dan Pihak Kedua menyatakan sanggup untuk bekerja pada Pihak Pertama."

Jadi tujuan yang hendak dicapai dengan adanya perjanjian kerja dari masing-masing pihak antara lain adalah Pihak Pertama mengharapkan keahlian dan kemampuan dari Pihak Kedua untuk dapat bekerja sesuai dengan tugas-tugas yang diberikan kepadanya, sedangkan bagi Pihak Kedua tujuan adanya perjanjian kerja adalah untuk mendapatkan penghasilan dan kesempatan bekerja.

(d) Ada prestasi yang harus dilaksanakan

Prestasi yang dimaksudkan adalah hak dan kewajiban yang harus dilaksanakan oleh masing-masing pihak. Adapun hak-hak dan kewajiban-kewajiban para pihak sebagaimana termuat dalam isi perjanjian kerja tersebut dapat dilihat pada Tabel tentang hak dan kewajiban bagi para pihak yang telah penulis jabarakan pada sub bab sebelumnya diatas.

(e) Ada bentuk tertentu

Perjanjian kerja yang dibuat oleh Tanamas Industry Community dibuat secara tertulis dengan maksud untuk dapat dijadikan sebagai alat bukti atas adanya hubungan kerja bagi masing-masing pihak yang bersangkutan. Perjanjian ini untuk selanjutnya dipegang oleh masing-masing pihak sebagai tanda bukti yang berkekuatan hukum, sebagaimana yang tertulis dalam Pasal 15 ayat (2) tentang Ketentuan Pelaksana yang berbunyi: "PKWT ini dibuat dalam rangkap 2 (dua) dan masing-masing memiliki kekuatan hukum yang sama.”

(f) Ada syarat-syarat tertentu

Di dalam pembuatan perjanjian kerja tercantum syarat-syarat untuk dapat melaksanakan hubungan kerja yang hendak dicapai. Syarat-syarat yang dimaksud adalah syarat-syarat yang 
bersifat spesifik dan yang bersifat umum yang dimulai dari Pasal 2 sampai dengan Pasal 16. Syarat yang bersifat spesifik antara lain adalah jabatan yang diberikan kepada Pihak Kedua untuk dapat diemban dan dilaksanakan dengan baik, besaran gaji yang diberikan dan jangka waktu hubungan kerja yang akan dilaksanakan oleh kedua belah pihak. Sedangkan syarat-syarat yang bersifat umum antara lain adalah jumlah hari cuti yang diberikan kepada Pihak Kedua, jam kerja, Tunjangan Hari Raya, rahasia perusahaan, dan ketentuan pelaksanaan.

Selanjutnya mengenai sah atau tidaknya suatu perjanjian yang dibuat, Pasal $1320 \mathrm{KUH}$ Perdata menyebutkan adanya empat syarat untuk sahnya suatu perjanjian, yakni:

(a) Sepakat mereka yang mengikatkan diri

Sepakat mereka yang mengikatkan diri; maksudnya adalah kedua belah pihak yang mengadakan perjanjian tersebut sepakat, setuju serta seia sekata atas hal-hal yang di perjanjikannya. Manakala keseluruhan hal-hal dalam isi perjanjian terlah terpenuhi, maka kata sepakat yang merupakan unsur utama dari empat syarat dalam suatu perjanjian tersebut telah terpenuhi. Di dalam perjanjian kerja Tanamas Industry Community memberikan pernyataan bahwa kedua belah pihak sepakat dalam membuat perjanjian terdapat pada bagian pendahuluan, sub bagian resital yang berbunyi: "Kedua belah pihak secara bersama-sama sepakat untuk membuat Perjanjian kerja (PKWT) sesuai dengan syarat dan ketentuan sebagai berikut."

(b) Kecakapan untuk membuat suatu perjanjian

Kecakapan membuat suatu perjanjian; maksudnya adalah para pihak dalam suatu perjanjian adalah para pihak yang cakap untuk melakukan hubungan hukum yakni orangorang yang dinyatakan telah dewasa berdasarkan ukuran undang-undang, mereka yang tidak berada di bawah pengampuan, dan orang perempuan yang telah menikah tanpa harus mendapatkan izin dari suaminya (berdasarkan Surat Edaran Makamah Agung RI Nomor 3 Tahun 1963). Pihak-pihak yang mengadakan perjanjian kerja di Tanamas Industry Community adalah pihak-pihak yang secara hukum cakap untuk membuat perjanjian dimana Tanamas Industry Community yakni perusahaan sebagai Pihak Pertama yang dalam hal ini diwakili oleh kepala perwakilannya dan Pihak Kedua yang sudah cakap bertindak, berumur diatas 21 tahun dan tidak berada di bawah pengampuan. Identitas para pihak dapat dilihat pada bagian pendahuluan dari perjanjian kerja tersebut.

(c) Suatu hal tertentu

Suatu hal tertentu; maksudnya adalah adanya sesuatu yang harus telah ditentukan dan disepakati di dalam suatu perjanjian. Suatu hal tertentu yang ada di dalam perjanjian kerja di 
Tanamas Industry Community adalah hal hubungan kerja antara Pihak Pertama dengan Pihak Kedua. Bila dilihat di dalam perjanjian kerja di Tanamas Industry Community adanya hubungan kerja yang merupakan suatu hal tertentu tersebut, tentang luasnya kesepakatan yang menyebutkan bahwa Pihak Pertama memperkerjakan Pihak Kedua dan Pihak Kedua menyatakan sanggup untuk bekerja kepada Pihak Pertama. Dengn demikian dari adanya katakata "memperkerjakan" dan "menyatakan sanggup untuk bekerja" merupakan bentuk hubungan kerja.

(d) Suatu sebab yang halal

Suatu sebab yang halal; maksudnya adalah suatu sebab yang menimbulkan adanya perjanjian dimana sebab tersebut tidak dilarang oleh undang-undang, tidak bertentangan dengan kesusilaan dan ketertiban umum. Sebab yang halal dalam pembuatan perjanjian kerja di Tanamas Industry Community adalah dikarenakan adanya Pihak Pertama membutuhkan tenaga kerja untuk bekerja kepadanya untuk satu posisi kerja dan Pihak Kedua membutuhkan pekerjaan sesuai dengan kemampuan yang dimilikinya. Sebab itulah yang menjadi dasar kedua belah pihak mengadakan perjanjian kerja yang pada akhirnya menimbulkan suatu hubungan kerja.

Adapun ketentuan tentang syarat-syarat sah yang telah disebutkan diatas dapat dibedakan menjadi dua macam syarat, yakni: syarat subyektif dan syarat obyektif. Syarat subyektif adalah syarat yang menyangkut mengenai suatu subyek yang diisyaratkan. Dalam hal ini yang termasuk ke dalam syarat subyektif adalah yaitu tentang syarat sepakat antara pihak yang mengikatkan diri dan syarat tentang kecakapan untuk membuat suatu perjanjian. Sedangkan syarat obyektif adalah syarat yang mengatur mengenai obyek yang diperjanjikan dalam perjanjian tersebut. Yang termasuk di dalam syarat obyektif ini adalah yaitu syarat tentang hal tertentu dan syarat tentang suatu sebab yang halal.

Bilamana salah satu syarat dalam syarat subyektif tidak terpenuhi maka salah satu pihak yang mengadakan perjanjian mempunyai hak untuk memohon kepada Hakim untuk membatalkan perjanjian tersebut. Dan bilamana salah satu syarat dalam syarat obyektif tidak terpenuhi maka perjanjian tersebut adalah batal demi hukum, karenanya tujuan para pihak untuk membuatu suatu perjanjian menjadi batal, hal ini karena obyek yang diperjanjikan batal, maka perjanjian itu batal demi hukum.

Di dalam membuat perjanjian, asas yang utama yang harus diperhatikan adalah asas kebebasan berkontrak atau disebut juga freedom of contract. Ketentuan mengenai asas ini terdapat di dalam Pasal 1338 KUH Perdata yang menyatakan bahwa semua perjanjian yang 
dibuat berlaku sebagai undang- undang bagi mereka yang mebuatnya. Dengan adanya asas kebebasan berkontrak ini, para pihak bebas untuk:

(a) Membuat atau tidak membuat perjanjian.

(b) Memilih dan menentukan mengenai dengan siapa akan melakukan perjanjian tersebut.

(c) Mengatur bagaimana isi perjanjian tersebut.

(d) Menentukan bentuk perjanjian tersebut.

(e) Menentukan cara membuat perjanjian tersebut.

Namun kebebasan ini tidak serta merta bebas dari segalanya, terdapat batasan dalam membuat perjanjian yakni tidak bertentangan dengan undang-undang, kesusilaan dan ketertiban. Selebihnya dari pada itu, para pihak dapat secara bebas membuat perjanjian yang diinginkan.

Mengenai perjanjian kerja dapatlah dikatakan bahwa perjanjian kerja adalah sebagai dasar lahirnya hubungan kerja. Hubungan kerja adalah hubungan antara pekerja dengan pengusaha yang terjadi setelah adanya perjanjian kerja, yakni suatu perjanjian dimana pekerja menyatakan kesanggupan untuk bekerja pada pihak perusahaan dengan menerima upah dan pengusaha menyatakan kesanggupannya untuk memperkerjakan pekerja dengan membayar upah (Husni, 2003).

Dalam hal perjanjian kerja di Tanamas Industry Community dapat dikatakan bahwa perjanjian kerja yang dibuat adalah perjanjian kerja dalam bentuk baku dimana dalam pembuatan bentuk dan syarat-syarat dalam perjanjian tersebut telah ditetapkan sepihak oleh Tanamas Industry Community sebagai pengusaha. Undang-Undang Republik Indonesia No. 8 Tahun 1999 tentang Perlindungan Konsumen mendefiniskan perjanjian baku yang disebut sebagai klausul baku adalah setiap aturan atau ketentuan dan syarat-syarat yang telah dipersiapkan dan ditetapkan terlebih dahulu secara sepihak oleh pelaku usaha yang dituangkan dalam suatu dokumen dan/atau perjanjian yang mengikat dan wajib dipenuhi oleh konsumen. Sehingga kalau diartikan secara harafiah dalam perjanjian kerja yang dibuat secara baku adalah setiap aturanaturan yang dituangkan dalam satu bentuk perjanjian kerja yang mana telah dipersiapkan dan ditetapkan terlebih dahulu secara sepihak oleh pengusaha dimana syarat-syarat tersebut mengikat dan wajib dipenuhi oleh pekerja/karyawan.

Perjanjian kerja yang dibuat secara baku oleh pihak pengusaha tidak jarang menimbulkan permasalahan di dalam pelaksanaanya, dengan kata lain terdapat pihak yang dirugikan yakni si pekerja sebagai pihak yang lemah. Adanya asas kebebasan berkontrak pada prinsipnya memberikan kebebasan dalam pembuatan perjanjian kepada masing-masing pihak untuk: membuat atau tidak membuat perjanjian, memilih dan menentukan mengenai dengan 
siapa akan melakukan perjanjian tersebut, mengatur isi perjanjian tersebut, menentukan bentuk perjanjian tersebut, dan menentukan cara membuat perjanjian tersebut. Namun bila mana perjanjian tersebut dibuat dalam bentuk baku maka kebebasan yang diberikan tidak sepenuhnya dimiliki oleh salah satu pihak, yakni pihak dalam posisi yang lemah yang dalam hal ini adalah pekerja/Pihak Kedua. Pekerja tidak lagi bebas untuk mengatur isi perjanjian dan menentukan cara membuat perjanjian tersebut dikarenakan perjanjian tersebut telah dibuat secara baku oleh pengusaha/Pihak Pertama. Ketidakbebasan inilah yang ditemukan dalam pembuatan perjanjian kerja di Tanamas Industry Community.

Meski ditemukan ketidakbebasan dalam pembuatan perjanjian kerja di Tanamas Industry Community namun adanya sepakat/setuju atas perjanjian yang dibuat dapat dilihat dari ada tidaknya tandatangan para pihak yang dibubuhkan pada perjanjian tersebut. Mengenai penandatanganan suatu perjanjian ini oleh Purwahid Patrik menyatakan bilamana salah satu pihak telah menandatangani suatu perjanjian, maka hal itu berarti bahwa ia telah setuju atau sepakat dengan apa yang tercantum dalam perjanjian tersebut (Patrik, 1986). Selanjutnya, Munir Fuady menyatakan bahwa penandatanganan suatu perjanjian mengandung arti bahwa para pihak sudah setuju dengan perjanjian tersebut, termasuk sudah setuju dengan isinya. Berdasarkan pernyataaan tersebut dapatlah disimpulkan bahwa sebelum menandatangi suatu perjanjian diharapkan untuk mengerti terhadap isi perjanjian tersebut (Fuandy, 2001).

Perjanjian kerja yang dibuat secara baku tersebut tidak mungkin diadakan tawar menawar oleh pihak yang memiliki posisi yang lemah sehingga baginya hanya ada dua pilihan yaitu menerima atau menolak perjanjian tersebut. Melalui penandatanganan sebuah perjanjian sudah terbukti secara fakta bahwa pihak yang posisi tawarnya lemah pun dianggap oleh pengusaha menyepakati segala isi perjanjian yang dimaksudkan. Menerima berarti bersedia untuk memenuhi segala syarat-syarat yang cenderung hanya memberikan keuntungan bagi pengusaha dan kerugian bagi pekerja.

Berdasarkan uraian di atas maka "wajar" jika Tanamas Industry Community menganggap bahwa setelah ditandatanganinya perjanjian kerja oleh kedua belah pihak, maka perjanjian tersebut menjadi sah dan mengikat sebagai undang-undang berdasarkan kesepakatan kedua belah pihak sebagaimana dalam Pasal 1337-1338 KUH Perdata. Dinyatakan pula diatas bahwa asas kebebasan berkontrak tidak diterapkan sepenuhnya dalam perjanjian kerja yang dibuat oleh Tanamas Industry Community dikarenakan kebebasan untuk menentukan isi perjanjian dan cara membuat perjanjian tersebut tidak dimiliki oleh pekerja/Pihak Kedua, dengan kata lain kebebasan mutlak hanya ada pada pengusaha/Pihak Pertama. Hal tersebut dikarenakan 
perjanjian kerja tersebut adalah perjanjian yang berbentuk baku dimana isi dan ketentuan yang ada di dalam perjanjian kerja tersebut telah ditetapkan sedemikian rupa oleh Tanamas Industry Community sebagai pengusaha/Pihak Pertama sementara pekerja/Pihak Kedua hanya tinggal memilih untuk menerima atau tidak menerima perjanjian kerja tersebut.

Jika semua syarat-syarat yang telah dijabarkan tersebut diatas bersifat kumulatif artinya hak dipenuhi semuanya baru dapat dikatakan bahwa perjanjian tersebut sah. Syarat kemauan bebas kedua belah pihak pada kemampuan atau kecakapan kedua belah pihak dalam membuat perjanjian dalam hukum perdata disebut sebagai syarat subjektif karena menyangkut mengenai orang yang membuat perjanjian, sedangkan syarat adanya pekerjaan yang diperjanjikan dan pekerjaan yang diperjanjikan harus halal disebut sebagai syarat objektif karena menyangkut objek perjanjian. Jika syarat objektif tidak dipenuhi, maka perjanjian itu batal demi hukum artinya dari semula perjanjian tersebut dianggap tidak pernah ada. Jika yang tidak dipenuhi syarat subjektif, maka akibat hukum dari perjanjian tersebut dapat dibatalkan, pihak-pihak yang tidak memberikan persetujuan secara tidak bebas, demikian juga oleh orang tua/wali atau pengampu bagi orang yang tidak cakap membuat perjanjian dapat meminta pembatalan perjanjian itu kepada hakim.

\section{Simpulan}

1. Adapun yang menjadi alasan pihak Tanamas Industry Community mengikat buruh dengan perjanjian kerja adalah sebagai berikut:

a) Apabila pekerjaan telah selesai dikerjakan oleh pekerja tetap, dan pekerja tidak mempunyai pekerjaan lagi, perusahaan tetap harus memberikan: ASTEK; Tunjangan; Cuti 12 hari; dan Upah 1 (satu) bulan penuh, dan;

b) Tanamas Industry Community Kota Cirebon mengikat tenaga kerja dalam perjanjian kerja untuk waktu tertentu karena pekerjaan yang berlangsung di Tanamas Industry Community Kota Cirebon yang tujuan usahanya adalah perkebunan jika dilihat dari sifat, jenis atau kegiatannya akan selesai dalam waktu tertentu.

2. Implementasi asas kebebasan berkontrak dalam pelaksanaan perjanjian kerja antara buruh dan Tanamas Industry Community di Kota Cirebon jika ditinjau dari isi perjanjian untuk waktu tertentu tersebut tidak memenuhi asas proporsionalitas serta dapat merugikan pihak buruh atau karyawan karena sebagian dari isi perjanjian kerja tersebut mewajibkan buruh atau karyawan mentaati peraturan yang telah ditetapkan oleh perusahan dalam bentuk (standart contract), dan karena hal tersebut dapat berdampak merugikan salah satu pihak 
yaitu buruh.

\section{DAFTAR PUSTAKA}

Achmad Ali, Menguak Tabir Hukum (Suatu Kajian Filosofis dan Sosiologis), (Jakarta: Penerbit Toko Gunung Agung, 2002)

Achmad Busro, Hukum Perikatan Berdasar Buku III KUH Perdata, (Yogyakarta: Pohon Cahaya, 2002)

Djumadi, Hukum Perburuhan Perjanjian Kerja, (Jakarta: PT. RajaGrafindo Persada, 1995

Djohari Santosa dan Achmad Ali, Beberapa Asas-Asas Hukum Pembuktian Dan Asas-Asas Hukum Perjanjian Di Dalam Hukum Perdata Di Indonesia, (Yogyakarta: Fakultas Hukum UII)

FX.Djualmiadji, Perjanjian Kerja, (Jakarta: Bumi Aksara, 1994)

G. Kartasapoetra, dkk, Pokok-pokok Hukum Perburuhan, (Bandung: Armico, 1985)

Herlien Budiono, Ajaran Umum Hukum Perjanjian dan Penerapannya di Bidang Kenotariatan, (Bandung: PT. Citra Aditya Bakti,2012) 